(C-02)

\title{
Green Energy Initiatives by Tokyo Cement Group
}

\author{
Kandapola C.S. \\ Tokyo Cement (Lanka) PLC, Colombo
}

\begin{abstract}
The principal causal factor of global warming identified is the excessive release of $\mathrm{CO}_{2}$ to the atmosphere by anthropogenic activity. The primary cause identified for this phenomenon is the combustion of hydrocarbons such as fossil fuels, natural gases, peat and coal for the derivation of energy for human activity. More recently, the production of cement has also been identified as an excessive emitter of $\mathrm{CO}_{2}$, due to the release of this gas as a by-product of the process treating limestone. Thus for reducing the release of $\mathrm{CO}_{2}$, which is principally responsible for climate change, emphasis is on the use of alternative sources of energy, preferably those that do not utilize fossil fuels but use renewable sources.
\end{abstract}

Tokyo Cement Company was launched the early 1980's in the eastern port city of Trincomalee to cater to the demand of much needed cement for the housing and construction industry of Sri Lanka. Since the inception of operation in early 1980's the production process depended on the electricity from national grid. In 2008 Tokyo Cement Company commissioned Sri Lanka's first of its kind $10 \mathrm{mw}$ biomass power plant fueled by rice husk, saw dust and wood of Gliricidia sapium. The biomass power plant provided stable power supply in the production of cement while displacing electricity from the national grid same time supplying the excess to the national grid. The project is supported by UNFCCC carbon credit program and annually generates $40,000 \mathrm{t} \mathrm{CO}_{2 \mathrm{e}}$.

In 2014, the Tokyo Cement Group has commissioned its second wood based dendro power plant in the city of Mahiyanaganaya. The $5 \mathrm{MW}$ dendro power project is fueled by Gliricidia sepium wood supplied by the out growers in the area.

The aim of our organization is to promote enterprises that help Sri Lanka, both economically and environmentally. The organization firmly believes that this objective is met through the development of Green cement using Green energy, and thus is a step in the correct direction. Hence the organization has embarked upon these renewable energy projects in Trincomalee and Mahiyanganaya with $15 \mathrm{MW}$ capacity. Although we are walking on a tightrope, we are proving that our aspirations are being realized and thus hope that our venture will be the first of many, to help our motherland and its populations receive energy and products through Green energy in an environmentally friendly manner.

Keywords: $\mathrm{CO}_{2}$, Dendro power, Green energy

Proceedings of the International Forestry and Environment Symposium 2016, Department of Forestry and Environmental Science, University of Sri Jayewardenepura, Sri Lanka. 